TITLE:

\title{
An Experimental Study of the Spino-olivary Fibers in the Rabbit and the Cat(Abstract_要旨)
}

\author{
$\operatorname{AUTHOR}(S)$ :
}

Mizuno, Noboru

\section{CITATION:}

Mizuno, Noboru. An Experimental Study of the Spino-olivary Fibers in the Rabbit and the Cat. 京都大学, 1966, 医学博士

\section{ISSUE DATE:}

1966-03-23

URL:

http://hdl.handle.net/2433/211775

RIGHT: 


\section{【180】}

氏 名水 野

学位の種類医学 博士

学位記番号論医 博 第 249 号

学位授与の日付 昭 和 41 年 3 月 23 日

学位授与の要件 学 位 規 則第 5 条第 2 項該当

学位論文題目 An Experimental Study of the Spino-olivary Fibers

in the Rabbit and the Cat

（家鬼および猫における脊䯣オリーブ線維の実験的研究）

論文調査委員教主授查岡本道雄 教授堀井五十雄 教 授 西村秀雄

\section{論文内容の要旨}

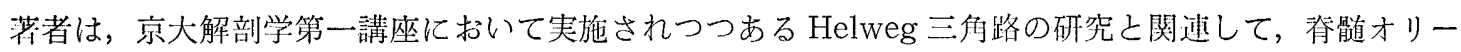
ブ路に比較解剖学的考察を加えるため，実験動物として，従来脊䯣オリーブ路の起始細胞として論議のあ

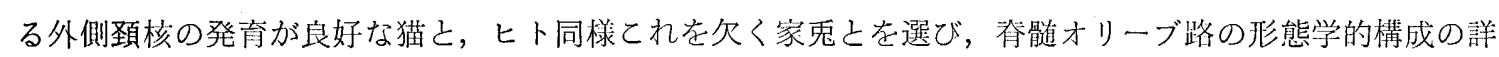
細を追究した。

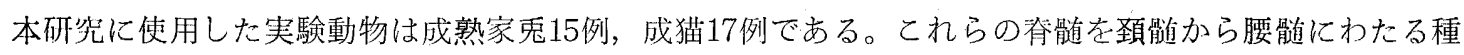
々の高さで傷害して，発生する変性線維を脊䯣からオリーブ核に追跡した。その際，從来報售されている 脊髄オリーブ路に関する知見にみられる種々の差異には, それぞれの研究者が使用した実駼方法の差異に 基づくものが多いと考えら机るところから，Nauta 法抢よび Marchi 法を同時に行ない，また Hägqvist 法，その他の方法をあ併用して，それぞれの結果老比較検討した。

1）脊髄よりオリーブ核に連絡する線維は脊䯣の各節の後角执よび，抢そらくは中間層から出て，両側 の前索とこれに隣接する前側索の部位を次第に前索表層に集まる傾向を示しつつ上行する。同側性の

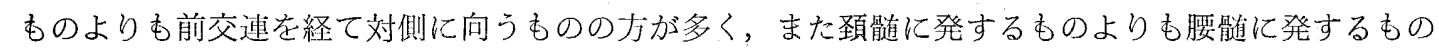
の方が多い。

2）オリーブ核内の変性終末は背側副オリーブ核で最も豊富であり，その頭背内側の部分を除きほぼ全 体に分布する。内側副オリーブ核内の変性終末はほぼ尾方 $1 / 3$ に限局し，尾端に近い部位では内側の 一部を除きほぼ全体に分布するが，豊富な分布がみられるのは主として外側半である。頚㭪道上部 $\left(\mathrm{C}_{1}\right.$, $\mathrm{C}_{2}$ ）の傷害例で，背帽の尾側半に時に小量の変性終末を認めたが，てれらは三叉神経脊髄路核より出 る線維の終末である可能性が大である。また， $\beta$ 核，背内側細胞柱には変性終末を認めなかった。主 核については，背側板と腹側板との移行部に，洔に変性終末とまぎらわしい像がみら扎たが，明確な 変性終末像ではなく, 通過線維であると考えられる。

3）脊䯣オリーブ路のみを，脊䯣網様休路と独立に変性せしめるととが不可能なとと，および，脊髄よ 
り上行する変性線維群のオリーブ核周辺にお竹態度より，脊髄オリーブ線維の過半数は，主として 脊䯣網様体路の，また一部は脊髄視床路の側枝之考えられるが，背側および内側副オリーブ核の下端 に近く終止するものの中には独立の脊髄オリーブ路の終末むかなり多数存在するものと考えられる。

4）後角は健全で外側䅡核が損傷された猫の例で，対側オリーブ核およびその周辺の変性線維の分布を みるに，第一ないし第二額䯣節前索切截例の同側オリーブ核および周辺の変性線維の分布と比較し て，量的な差以外にはほとんど差がなく，外側䅡核から出る線維がオリーブ核に連絡する可能性は否 定できない。しかし，オリーブ核内の変性終末は，外側頝核を含む頚随後角損傷例より屯腰䯣後角損 傷例でむしろ多い。したがって外側頝核が脊髄オリーブ路の主な起始細胞であるとは考えがたい。

5）猫で外側頝核の傷害例および第二頚䯣以高での前索切截例で脊啃道視床路の変性がみられるのに対し て，外側頝核を欠く第三頝㭪道以下の傷害例ではこの神経路の変性はみられない。このとよより外側頝 核は春䯣視床路の起始細胞であり，外側頝核よりオリーブ核に連絡する線維は脊檤視床路の側枝であ ると考えられる。したがって，外側頚核が脊艏とオリーブ核との連絡に沶いて特別の位置を占めると は考えがたく，猫と家鬼の春䯣オリーブ路にはその構成上本質的な差異はみとめられない。

\section{論交賽查の結果の要旨}

著者は京大解剖学第一講座において行なわれている Helweg三角束の研究と関連して奉髄とオリーブ核 の線維連絡について実験的研究を行なったものであって動物として家志と猫を選んだのは, 従来少ら脊髄 オリーブ路の起始細胞として論議のある外側頝核が前者では欠如し，後者にのみ存するからである。実験 は家雭 15 例成猫 17 例春䯣を頝髅から腰髄にわたる種々の高さで切断し，変性線維を Marchi 法と Nauta 法で追求した。その成績は

1）春䯣よりオリーブ核に至吕線維は各節の後角と扢そらくは中間層から出る。同側よりも対側のもの が多い。

2）オリーブ核内の終止部は背側ならびに内側副オリーブ核であって主核には終らぬ。

3）尛䯣オリーブ線維の過半数は主として脊髄網様体路または一部脊髄視床路の側枝と考えられる。

4）外側頝核を含む傷害と含まないもの，また傷害の高さの相違によるオリーブ核内の変性線維量の比 較により外側澒核が脊髄オリーブ路の主な起始細胞であるとは考えられない。

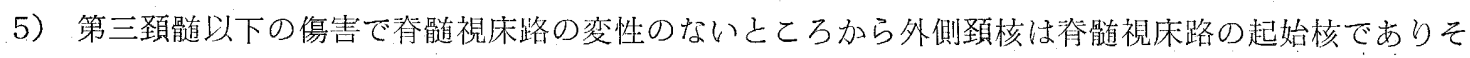
の側枝がオリーブ核に至る。

本論文は学術上有益にして医学博士の学位論文として洒值あるものと認定する。 